Article

\title{
Evaluation of Different Roof Types Concerning Daylight in Industrial Buildings during the Initial Design Phase: Methodology and Case Study
}

\author{
Theodora Mavridou ${ }^{1, *}$ and Lambros T. Doulos ${ }^{2,3}$ \\ 1 School of Civil Engineering and Surveying, Faculty of Technology, University of Portsmouth, \\ Portsmouth PO1 3AH, UK \\ 2 Lighting Laboratory, School of Electrical and Computer Engineering, \\ National Technical University of Athens, Zografou, 15780 Athens, Greece \\ 3 School of Applied Arts, Lighting Design, Hellenic Open University, 26335 Patra, Greece \\ * Correspondence: dora.mavridou@port.ac.uk
}

Received: 25 June 2019; Accepted: 12 July 2019; Published: 16 July 2019

\begin{abstract}
Used properly, daylight can provide visual comfort, reduce energy consumption and improve health and safety at work. This paper investigates the influence that different roof types, (i.e., sawtooth roof, skylight and monitor), have on daylight levels, along with the construction cost in an industrial environment in Athens, Greece. Construction costs and daylight adequacy/uniformity are antagonistic phenomena, since as the distance between the roof openings increases, the construction cost is minimised, while the daylight levels and the uniformity are reduced. Therefore, an optimisation method is proposed in order to find the optimum distance between the roof openings. The selected building is a representative unit of Greek industrial facilities, while the optimisation method is based upon a multiparametric approach. This consists of three (3) different roof opening arrangement types with different geometric characteristics. The daylight metrics used are the Daylight Area, the Daylight Factor, the Mean Daylight Autonomy, the Uniform Daylight Index and the Annual Sunlight Exposure. Overall, sawtooth roofs represent the best choice for daylight provision in industrial buildings at the examined geographic location. Using the aforementioned optimisation method, the optimum solution of distances between the roof openings ranges from $10 \mathrm{~m}$ to $13 \mathrm{~m}$.
\end{abstract}

Keywords: daylight; energy conservation; industrial buildings; optical comfort

\section{Introduction}

Green building notions [1-11] and energy autonomy are becoming increasingly important in the last decades, especially in the industrial sector, where energy costs from machinery in the past used to overshadow other aspects of energy consumption. As progressively traditional approaches of manufacturing have yielded to leaner methods of production and management systems, there has been an increased pressure on architecture to focus and address other aspects of energy "waste". Nowadays there is a worldwide interest, together with a considerable financial expenditure, in the quest for a better utilisation of available resources and a reduction in reliance on traditional "wasteful" techniques of operation. Furthermore, there is an increased demand for solutions that can also be applied in the form of retrofits to existing building structures as well. This signifies the need for an in-depth study of the interrelation between architectural characteristics and daylight [12-15]. While the selections of the luminaires [16-18] and the corresponding lighting control [19-25] are crucial for the calculation of energy consumption, the building form and the corresponding impact of the daylight $[26,27]$ determines the energy savings potential, and is still an important issue at the initial design stage of a building. Therefore, the need to create an accurate mathematical model is apparent. This work 
investigates the influence of different opening types and their arrangements in the overall daylight provision in an industrial building.

There have been several studies in daylighting [25-37]. Tsangrassoulis et al. [38] examined the hybrid daylighting system, Doulos et al. [39-41] investigated the relationship between dimming and daylighting. Kontadakis et al. [42] examined an active sunlight redirection system for daylight, with various studies investigating the effect of daylight driven from daylight systems and devices inside various types of buildings [43,44]. Huang et al. [45] utilized statistic tools and symmetry properties to determine an exponential relationship between luminosity and CCT in red-green-blue (RGB) LED and OLED light sources. Such a relationship presents an option to remove the effects of CCT in colour evaluation standards, as well as to provide a guideline for adjusting visual experiences solely by adjusting the luminosity when creating a lighting system [45].

Many studies have investigated the relationship between daylighting and the particular geometry of industrial buildings. Chena et al. [46] showed that more than $33.3 \%$ of the factory area could meet the standard requirements for work spaces on the sunny day, as the heating energy consumption increased with the reduction of artificial lighting. Asdrubali [47] examined the evaluation of the influence of the characteristics of 11 different sawtooth roofs. Bellia et al. [48] investigated a lighting retrofit intervention for energy savings and comfort optimisation in an industrial building in Nola, Italy. Paule et al. [49] examined a daylighting optimisation method in a new factory in Bordes, France. Wang et al. [50] examined the energy consumption and overheating in a UK industrial building with rooflights. Stojkovic et al. [51] investigated how the daylighting performance of an historic industrial building can be adapted into an office building. Katunsky et al. [52] dealt with a daytime lighting assessment in Textile Factories. Acosta et al. [53-55] dealt with the investigation of top lighting systems. The studies examined the daylighting design with light scoop skylights and presented the performance of lightwell skylights and monitor skylights.

The majority of the studies on industrial buildings concerning lighting is focused on to efficient artificial/daylight systems, rather than on the effect of the architectural structural shell to the lighting performance. The main scopes of this paper are: (a) The examination of how different roof openings affect the daylight performance of the building according to their type, shape, geometric orientation of the structure for a given geographical area during the design phase, and (b) how these factors can be optimised according to daylight. In more detail, this work identifies the effects of different roof types and opening geometries to the overall ingress indices of natural light and their effectiveness as complementary or exclusive light sources in an industrial environment in the Athens, Greece region ( $\left.37^{\circ} 59^{\prime} 02.3^{\prime \prime} \mathrm{N} 23^{\circ} 43^{\prime} 40.1^{\prime \prime} \mathrm{E}\right)$. Three types of roof openings, which are quite common in Greece, the sawtooth roof, the skylight and the monitor, were tested, using a number of daylight metrics and LEED protocol. As already mentioned, an optimisation method was used in order to find the optimum distance between the openings, counterbalancing all of the factors involved. As the distance between the roof openings is increased, the construction cost is minimised while the lighting adequacy is deteriorated.

\section{Materials and Methods}

To apply the multiparametric approach three different roof opening types were used (i.e., saw tooth roof, skylight and monitor, Figure 1) with various geometrical characteristics (width and height) and orientation, representing the most common construction types of industrial buildings in Greece.

Using the aforementioned geometries, a series of simulations were performed. A number of different daylight indices have been calculated (i.e., Daylight Area 300 lx, Mean Daylight Factor, Daylight Factor $>2 \%$, Mean Daylight Autonomy, Mean Continuous Daylight Autonomy, Maximum Daylight Autonomy $>5 \%$, Uniform Daylight Index and Annual Sunlight Exposure). All indices were calculated using the Diva for Rhinoceros plugin. The typical industrial building ( $20 \mathrm{~m} \times 55 \mathrm{~m}$ footprint, $10 \mathrm{~m}$ height) in Greece was selected for the case study (Figure 2). The glazing height of each of the roof apertures was considered at $10 \mathrm{~m}$ above the reference plane $(0 \mathrm{~m})$. Figure 3 presents the overall steps 
used for the identification of the optimum design solution, balancing both structural characteristics and daylight metrics.
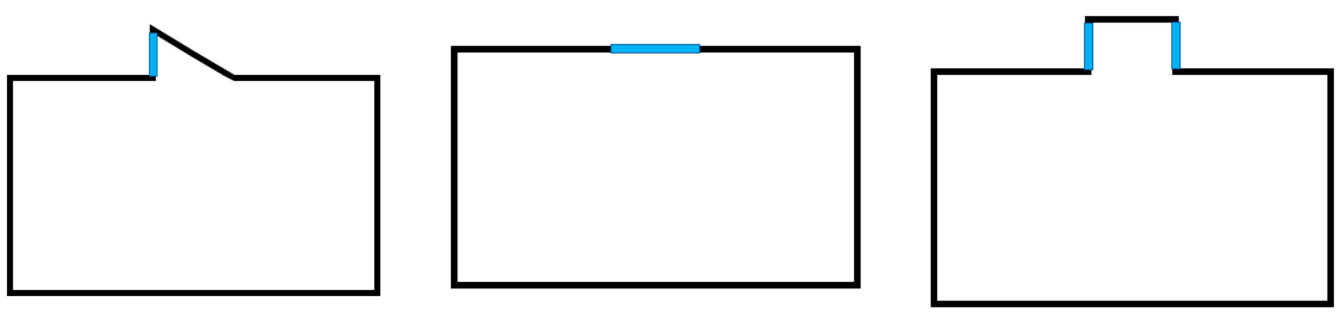

Figure 1. Sawtooth roof (Left), skylight (Middle) and monitor (Right).

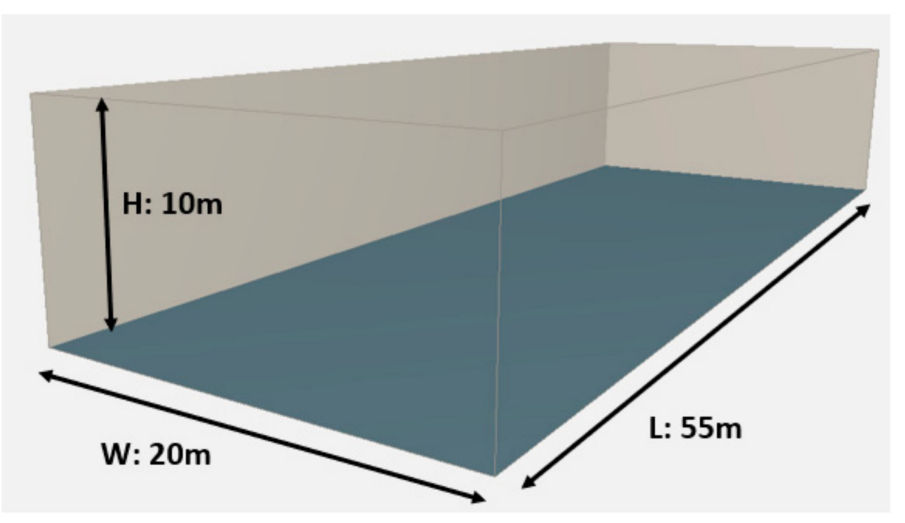

Figure 2. Dimensions of the industrial building (Length: $55 \mathrm{~m}$, width: $20 \mathrm{~m}$, height: $10 \mathrm{~m}$ ).

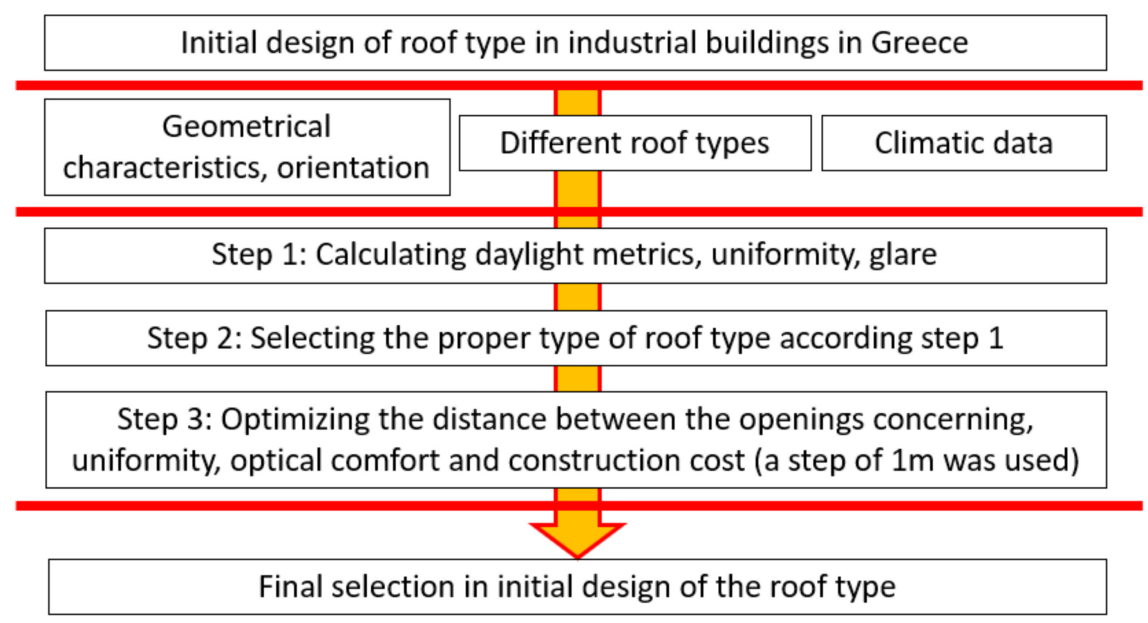

Figure 3. Diagram of the methodology.

Three different models were used, carrying out the same building shell, but different geometrical characteristics of their roof apertures (Figures 4-6). Table 1 provides the breakdown of the case studies selected, and presents the parameters examined, resulting in 72 scenarios. Table 2 presents the construction properties of the model.

Table 1. Breakdown of the 72 cases studies that were examined.

\begin{tabular}{ccccc}
\hline Opening Type & Height $(\mathbf{m})$ & Width $(\mathbf{m})$ & Glazing (Type) & Orientation \\
\hline Monitor & $3,4,5$ & $4,5,6$ & Clear & N-S, E-W \\
Saw Tooth & $3,4,5$ & $4,5,6$ & Clear & N, S, E, W \\
Skylight & N/A & $4,5,6$ & Clear, Opaque $(\times 2)$ & N-S, E-W \\
\hline
\end{tabular}


Table 2. Construction properties of the model.

\begin{tabular}{ccc}
\hline & Reflectance & Transmittance \\
\hline Floor & 0.20 & - \\
Walls & 0.50 & - \\
Ceiling & 0.70 & - \\
Glazing (Double pane) & & 0.80 \\
\hline
\end{tabular}

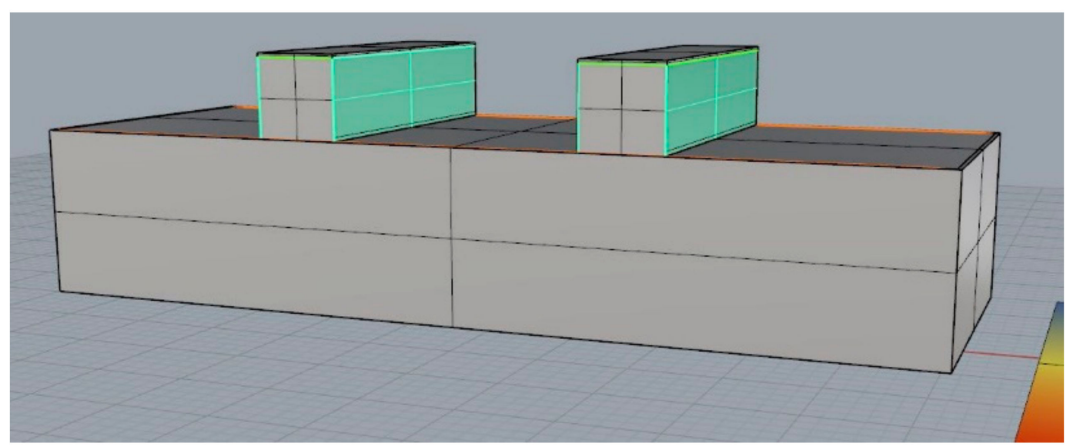

Figure 4. Monitor roof typical arrangement.

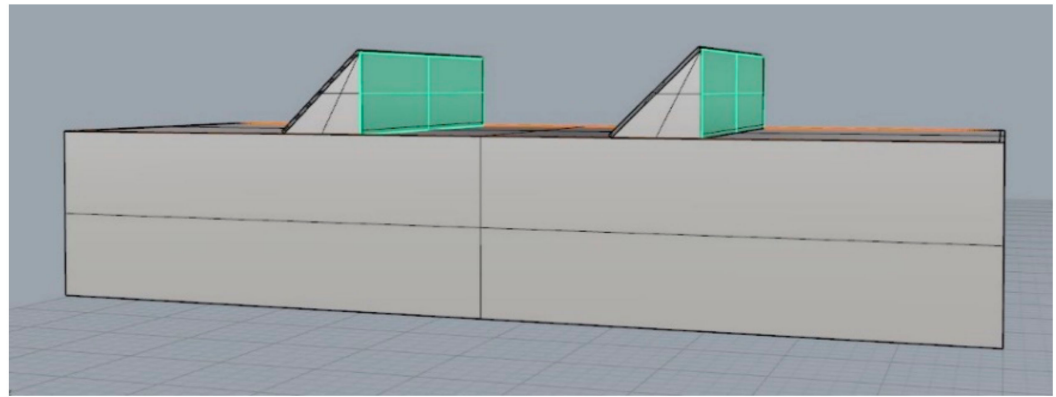

Figure 5. Saw tooth roof typical arrangement.

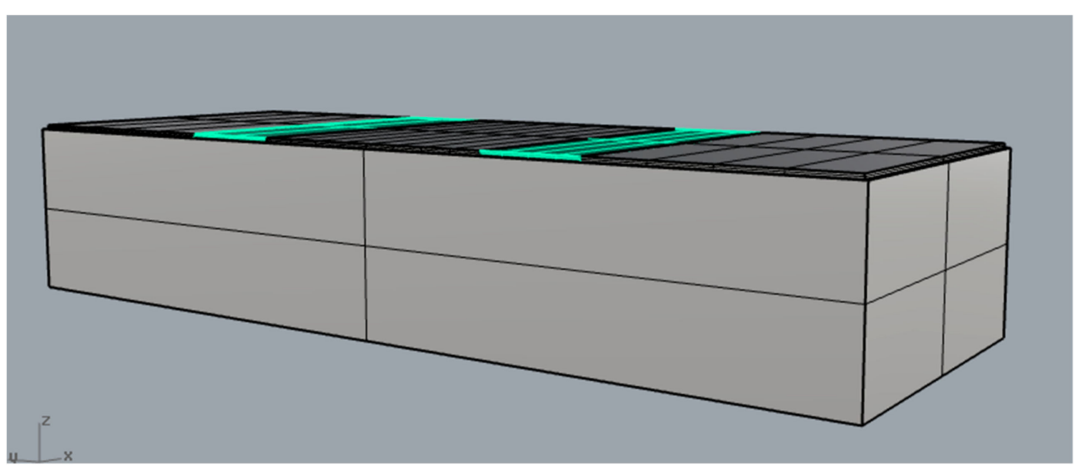

Figure 6. Skylight opening typical arrangement.

In each case, autonomy control of the daylight was performed for the monitor, skylight and sawtooth Roof ceiling aperture models, in order to extract the relevant daylight indicators. The percentage of the surface that receives sufficient illumination ( $>300 \mathrm{~lx}$ ) for more than $50 \%$ of the hours under investigation was selected as the initial criterion of acceptability. The definitions of the rest of the factors used in the investigation are given in Table 3. 
Table 3. Considered daylight metrics.

\begin{tabular}{ccl}
\hline Daylight Factor & DF & \multicolumn{1}{c}{ Physical Light Factor on a Given Unitary Surface } \\
\hline Useful Daylight Illuminance & UDI & $\begin{array}{l}\text { Percentage (\%) of the surface under with daylight levels } \\
\text { between 100-2000 lx during hours of use }\end{array}$ \\
\hline Spatial Daylight Autonomy & SDA & $\begin{array}{l}\text { Percentage (\%) of surface area under consideration having } \\
\text { daylight levels above 300 lx for a duration corresponding } \\
\text { to at least 50\% of the operating hours of the year. }\end{array}$ \\
\hline Annual Sunlight Exposure & ASE & $\begin{array}{l}\text { Percentage (\%) of the surface under consideration having } \\
\text { daylight levels (caused only by sunlight) from 1000 lx and } \\
\text { above for over 250 h during the year. }\end{array}$ \\
\hline $\begin{array}{c}\text { LEED v4 protocol (Currently not } \\
\text { applied in Industrial buildings) }\end{array}$ & LEED & $\begin{array}{l}\text { Two conditions must apply: A. ASE }<10 \%, \text { B. If SDA } \geq \\
55 \% \text { (two points) or 75\% (three points). }\end{array}$ \\
\hline
\end{tabular}

\subsection{Opening Types and Arrangements}

All of the parameters examined are presented in the Table 4.

Table 4. Roof opening types and geometries.

\begin{tabular}{cccccccc}
\hline \multicolumn{2}{c}{ Skylight } & \multicolumn{3}{c}{ Saw Tooth } & \multicolumn{3}{c}{ Monitor } \\
\hline Opaqueness (Type) & Orientation & Height $(\mathbf{m})$ & Width $(\mathbf{m})$ & Orientation & Height $(\mathbf{m})$ & Width $(\mathbf{m})$ & Orientation \\
\hline 3 Cases & 2 Cases & \multicolumn{2}{c}{ 3 Cases } & 4 Cases & 3 Cases & 2 Cases \\
\hline T1 & N-S/E-W & 4 & 3 & N/S/E/W & 4 & 3 & N-S/E-W \\
No & N-S/E-W & 4 & 4 & N/S/E/W & 4 & 4 & N-S/E-W \\
T2 & N-S/E-W & 4 & 5 & N/S/E/W & 4 & 5 & N-S/E-W \\
T1 & N-S/E-W & 5 & 3 & N/S/E/W & 5 & 3 & N-S/E-W \\
No & N-S/E-W & 5 & 4 & N/S/E/W & 5 & 4 & N-S/E-W \\
T2 & N-S/E-W & 5 & 5 & N/S/E/W & 5 & 5 & N-S/E-W \\
T1 & N-S/E-W & 6 & 3 & N/S/E/W & 6 & 3 & N-S/E-W \\
No & N-S/E-W & 6 & 4 & N/S/E/W & 6 & 4 & N-S/E-W \\
T2 & N-S/E-W & 6 & 5 & N/S/E/W & 6 & 5 & N-S/E-W \\
\hline
\end{tabular}

\subsection{Geometrical and Climatic Data Information}

In the next step the latitude and surface materials of the industrial building were selected. The city of Athens (37.90 N/23.73 W), Greece, was used in order to obtain the corresponding climatic data [56]. Due to the industrial use of the building, the basic working hours of industry in Greece were considered (07.00 LT-17.00 LT).

Athens presents climatic characteristics that are encountered in Mediterranean climates with relatively small rainfall and intense sunshine. The periods of sunshine, as well as the knowledge of weather data, were taken into account and were statistically processed (www.meteoblue.com) in order to be used in the simulation procedure. Therefore, the selected dates (Summer Solstice, Winter Solstice and Spring Equinox) have been chosen as being the typical days covering the whole spectrum of expected sunshine duration over the year (Figure 7). 


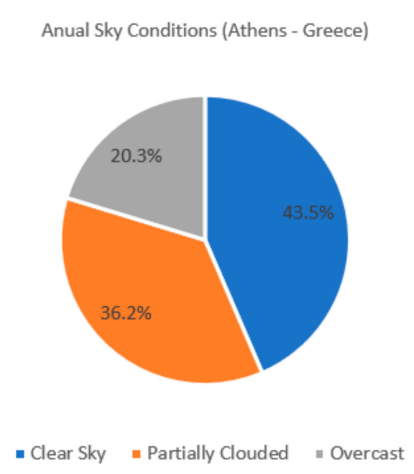

(a)

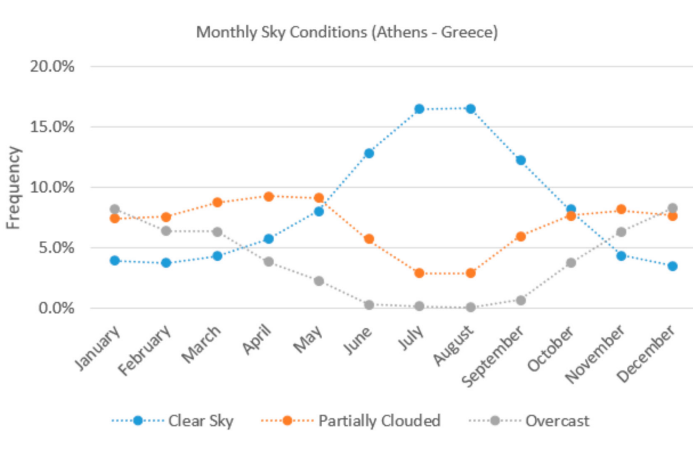

(b)

Figure 7. Typical (a) annual and (b) monthly sky conditions in Athens.

One of the key controls is the degree of daylight autonomy. The value of $300 \mathrm{~lx}$ was chosen as it was the most frequent target value in EN12464-1 [57] for industrial buildings. Analysing these data, it was found that most of the working places in an industrial building require $3001 x$. These operations represent more than $66 \%$ of industrial activities (EN 12464-1, Figure 8).

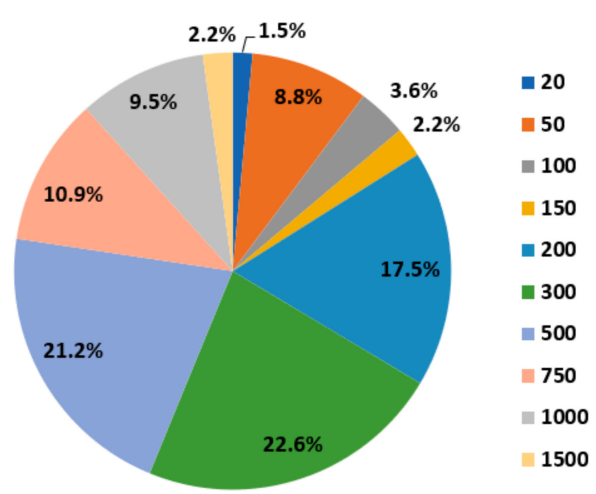

Figure 8. Frequency of the target illuminance values (lx) used for various industrial activities according to EN12464-1, 2014.

\section{Results}

The metrics examined were DA, SDA, ASE and the LEEDv4 daylight requirement. The corresponding results are summarized in Tables 5-7 for all of the 72 examined scenarios. The main goal of a successful design paradigm was to design and develop a best-case scenario that combines the appropriate daylight values (high values of DA and low ASE values) with the least amount of roof openings. Despite the lack of available LEED v4 values for industrial buildings, this research used the available LEED v4 criterion in order to assign the relevant points and identify its relevance with other parameters. A parametric analysis was performed based on and using the aforementioned factors, with Tables 5-7 summarising thee results for each of the three different types of roof apertures.

Monitor roof openings have MeanDA values ranging from $82 \%$ to $93 \%$, indicating the superiority of this case study against the others. In that regard, sawtooth roof openings provided lower values ranging from $56-74 \%$ for North $(\mathrm{N})$ orientation openings, 73-85\% for South (S) orientation openings and $65-79 \%$ for Eastern (E) and West (W) orientation. Finally, skylight roof openings exhibit the largest variation, which is strongly dependent upon the glass visible transmittance (Tvis). When glazing with Tvis 0.8 is used, MeanDA values are $>91 \%$. When the Tvis is reduced, MeanDA values are reduced as well. For example, when Tvis $=0.7$, MeanDA varies between $87-93 \%$, while when Tvis is 0.2 , MeanDA $<30 \%$. It is therefore evident that, according to the MeanDA metric, monitor roofs do present a consistently better performance, in terms of Daylight Autonomy behaviour, than the other types of openings. 
Table 5. Daylight Simulation Results for monitor type.

\begin{tabular}{|c|c|c|c|c|c|c|c|c|c|c|c|c|}
\hline Height (m) & $\begin{array}{c}\text { Width/Opaqueness } \\
\text { (m/type) }\end{array}$ & Orientation & $\begin{array}{c}\text { Daylit Area } \\
\text { DA }_{3001 x}[50 \%](\%)\end{array}$ & $\begin{array}{l}\text { Mean Daylight } \\
\text { Factor (\%) }\end{array}$ & $\begin{array}{c}\text { DF }>2 \% \\
(\%)\end{array}$ & $\begin{array}{c}\text { Mean DA } \\
(\%)\end{array}$ & $\begin{array}{c}\text { Mean } \\
\text { CDA (\%) }\end{array}$ & $\begin{array}{l}\text { DA_MAX } \\
>5 \%(\%)\end{array}$ & $\begin{array}{c}\text { UDI }_{<100-20001 x} \\
>50 \%(\%)\end{array}$ & SDA (\%) & ASE (\%) & $\begin{array}{r}\text { LEED } \\
\text { (Pts) }\end{array}$ \\
\hline 4 & 3 & N-S & 73 & 2 & 46 & 66 & 83 & 41 & 99 & 7.7 & 39.5 & 0 \\
\hline 4 & 3 & E-W & 73 & 2 & 46 & 63 & 82 & 34 & 97 & 18.2 & 35.7 & 0 \\
\hline 4 & 4 & N-S & 80 & 2.3 & 57 & 73 & 88 & 50 & 100 & 11.5 & 47 & 0 \\
\hline 4 & 4 & E-W & 80 & 2.3 & 57 & 71 & 87 & 43 & 100 & 23.4 & 40.6 & 0 \\
\hline 4 & 5 & N-S & 87 & 2.4 & 67 & 78 & 91 & 60 & 100 & 15.4 & 54 & 0 \\
\hline 4 & 5 & E-W & 87 & 2.5 & 66 & 76 & 90 & 48 & 100 & 28.7 & 44.8 & 0 \\
\hline 5 & 3 & N-S & 74 & 2.2 & 51 & 67 & 84 & 41 & 99 & 10.2 & 40.4 & 0 \\
\hline 5 & 3 & E-W & 74 & 2.2 & 51 & 65 & 83 & 36 & 97 & 21.4 & 36.7 & 0 \\
\hline 5 & 4 & N-S & 83 & 2.6 & 66 & 76 & 89 & 55 & 100 & 15.1 & 51.4 & 0 \\
\hline 5 & 4 & E-W & 82 & 2.6 & 65 & 74 & 88 & 49 & 100 & 32.2 & 45.6 & 0 \\
\hline 5 & 5 & N-S & 90 & 2.9 & 77 & 81 & 92 & 67 & 100 & 19.4 & 61.5 & 0 \\
\hline 5 & 5 & E-W & 90 & 2.9 & 77 & 80 & 91 & 56 & 100 & 38.3 & 50.3 & 0 \\
\hline 6 & 3 & N-S & 75 & 2.3 & 54 & 68 & 84 & 46 & 99 & 11.9 & 44.6 & 0 \\
\hline 6 & 3 & E-W & 74 & 2.3 & 54 & 66 & 83 & 40 & 97 & 25.6 & 41.2 & 0 \\
\hline 6 & 4 & N-S & 83 & 2.6 & 64 & 76 & 89 & 56 & 100 & 15.7 & 52.8 & 0 \\
\hline 6 & 4 & E-W & 82 & 2.6 & 63 & 74 & 88 & 49 & 100 & 31.6 & 47.8 & 0 \\
\hline 6 & 5 & N-S & 91 & 3.2 & 79 & 83 & 93 & 70 & 100 & 23.1 & 62.6 & 0 \\
\hline 6 & 5 & E-W & 91 & 3.2 & 79 & 81 & 92 & 58 & 100 & 44 & 53.5 & 0 \\
\hline
\end{tabular}

Table 6. Daylight Simulation Results for skylight type.

\begin{tabular}{|c|c|c|c|c|c|c|c|c|c|c|c|c|}
\hline Height (m) & $\begin{array}{l}\text { Width/Opaqueness } \\
\text { (m/type) }\end{array}$ & Orientation & $\begin{array}{c}\text { Daylit Area } \\
\text { DA }_{3001 x}[50 \%](\%)\end{array}$ & $\begin{array}{l}\text { Mean Daylight } \\
\text { Factor (\%) }\end{array}$ & $\begin{array}{c}\text { DF > 2\% } \\
(\%)\end{array}$ & $\begin{array}{c}\text { Mean DA } \\
(\%)\end{array}$ & $\begin{array}{c}\text { Mean } \\
\text { CDA (\%) }\end{array}$ & $\begin{array}{l}\text { DA_MAX } \\
>5 \%(\%)\end{array}$ & $\begin{array}{l}\text { UDI }_{<100-20001 x} \\
\quad>50 \%(\%)\end{array}$ & SDA (\%) & ASE (\%) & $\begin{array}{l}\text { LEED } \\
\text { (Pts) }\end{array}$ \\
\hline 4 & $\mathrm{~T} 1$ & N-S & 0 & 0 & 0 & 3 & 19 & 0 & 0 & 0 & 0 & 0 \\
\hline 4 & $\mathrm{~T} 1$ & E-W & 0 & 0 & 0 & 3 & 19 & 0 & 0 & 0 & 0 & 0 \\
\hline 4 & No & N-S & 85 & 6.1 & 74 & 81 & 91 & 71 & 78 & 65.6 & 66.5 & 0 \\
\hline 4 & No & E-W & 88 & 6.1 & 74 & 81 & 91 & 63 & 77 & 58.6 & 51.4 & 0 \\
\hline 4 & T2 & N-S & 77 & 4.3 & 69 & 74 & 87 & 63 & 100 & 41.8 & 62.3 & 0 \\
\hline 4 & $\mathrm{~T} 2$ & E-W & 79 & 4.3 & 69 & 73 & 87 & 55 & 97 & 41.6 & 50.9 & 0 \\
\hline 5 & $\mathrm{~T} 1$ & N-S & 0 & 0 & 0 & 6 & 24 & 0 & 0 & 57.2 & 72.6 & 0 \\
\hline 5 & $\mathrm{~T} 1$ & E-W & 0 & 0 & 0 & 6 & 24 & 0 & 0 & 0 & 0 & 0 \\
\hline 5 & No & N-S & 94 & 7.6 & 80 & 87 & 94 & 81 & 60 & 66.5 & 65.6 & 0 \\
\hline 5 & No & E-W & 94 & 7.6 & 80 & 87 & 94 & 71 & 62 & 65.8 & 55.1 & 0 \\
\hline 5 & T2 & N-S & 85 & 5.7 & 75 & 81 & 91 & 75 & 85 & 0 & 0 & 0 \\
\hline 5 & $\mathrm{~T} 2$ & E-W & 88 & 5.7 & 75 & 80 & 91 & 63 & 81 & 57.5 & 54.5 & 0 \\
\hline 6 & $\mathrm{~T} 1$ & N-S & 0 & 0 & 0 & 9 & 27 & 0 & 0 & 0 & 0 & 0 \\
\hline 6 & $\mathrm{~T} 1$ & E-W & 0 & 0 & 0 & 9 & 27 & 0 & 0 & 0 & 0 & 0 \\
\hline 6 & No & N-S & 99 & 9 & 85 & 90 & 95 & 87 & 50 & 0 & 77.8 & 0 \\
\hline 6 & No & E-W & 92 & 7.8 & 81 & 86 & 93 & 73 & 62 & 67.6 & 58.2 & 0 \\
\hline 6 & T2 & N-S & 92 & 6.8 & 80 & 86 & 93 & 82 & 72 & 63.6 & 77.6 & 0 \\
\hline 6 & T2 & E-W & 93 & 6.8 & 80 & 85 & 93 & 69 & 71 & 64.3 & 59.1 & 0 \\
\hline
\end{tabular}


Table 7. Daylight Simulation Results for saw tooth type.

\begin{tabular}{|c|c|c|c|c|c|c|c|c|c|c|c|c|}
\hline Height (m) & $\begin{array}{l}\text { Width/Opaqueness } \\
\text { (m/type) }\end{array}$ & Orientation & $\begin{array}{c}\text { Daylit Area } \\
\text { DA }_{3001 \mathrm{~lx}}[50 \%](\%)\end{array}$ & $\begin{array}{l}\text { Mean Daylight } \\
\text { Factor (\%) }\end{array}$ & $\begin{array}{c}\mathrm{DF}>2 \% \\
(\%)\end{array}$ & $\begin{array}{c}\text { Mean DA } \\
(\%)\end{array}$ & $\begin{array}{c}\text { Mean } \\
\text { CDA (\%) }\end{array}$ & $\begin{array}{l}\text { DA_MAX } \\
>5 \%(\%)\end{array}$ & $\begin{array}{c}\mathrm{UDI}_{<100-20001 \mathrm{~lx}} \\
>50 \%(\%)\end{array}$ & SDA (\%) & ASE (\%) & $\begin{array}{l}\text { LEED } \\
\text { (Pts) }\end{array}$ \\
\hline 4 & 3 & $\mathrm{~N}$ & 42 & 1.2 & 23 & 34 & 60 & 0 & 72 & 41.2 & 0 & 0 \\
\hline 4 & 3 & $\mathrm{~s}$ & 67 & 1.2 & 23 & 59 & 76 & 36 & 87 & 13 & 36.3 & 0 \\
\hline 4 & 4 & $\mathrm{~N}$ & 51 & 1.4 & 32 & 42 & 66 & 0 & 80 & 51.4 & 0 & 0 \\
\hline 4 & 4 & $\mathrm{~s}$ & 72 & 1.4 & 31 & 65 & 79 & 46 & 89 & 20.2 & 42.2 & 0 \\
\hline 4 & 5 & $\mathrm{~N}$ & 43 & 1.4 & 31 & 37 & 64 & 0 & 78 & 43.6 & 0 & 0 \\
\hline 4 & 5 & $\mathrm{~s}$ & 78 & 1.5 & 34 & 68 & 81 & 54 & 90 & 25.3 & 48.1 & 0 \\
\hline 5 & 3 & $\mathrm{~N}$ & 26 & 1.2 & 23 & 27 & 56 & 0 & 69 & 26.7 & 0 & 0 \\
\hline 5 & 3 & $\mathrm{~s}$ & 64 & 1.2 & 24 & 56 & 73 & 38 & 85 & 12 & 38.2 & 0 \\
\hline 5 & 4 & $\mathrm{~N}$ & 55 & 1.5 & 35 & 45 & 68 & 0 & 82 & 55.5 & 0 & 0 \\
\hline 5 & 4 & $\mathrm{~s}$ & 74 & 1.5 & 35 & 67 & 81 & 53 & 90 & 27.1 & 46.3 & 0 \\
\hline 5 & 5 & $\mathrm{~N}$ & 51 & 1.6 & 37 & 42 & 67 & 0 & 80 & 50.7 & 0 & 0 \\
\hline 5 & 5 & $\mathrm{~s}$ & 76 & 1.6 & 38 & 66 & 80 & 56 & 88 & 28.8 & 50 & 0 \\
\hline 6 & 3 & $\mathrm{~N}$ & 49 & 1.4 & 28 & 40 & 63 & 0 & 74 & 49.2 & 0 & 0 \\
\hline 6 & 3 & S & 69 & 1.4 & 28 & 63 & 79 & 44 & 89 & 19.3 & 40.6 & 0 \\
\hline 6 & 4 & $\mathrm{~N}$ & 58 & 1.7 & 37 & 48 & 69 & 0 & 82 & 57.8 & 0 & 2 \\
\hline 6 & 4 & S & 75 & 1.7 & 36 & 69 & 82 & 56 & 92 & 31.5 & 48.6 & 0 \\
\hline 6 & 5 & $\mathrm{~N}$ & 65 & 1.9 & 44 & 53 & 74 & 0 & 85 & 63.1 & 0 & 2 \\
\hline 6 & 5 & S & 82 & 1.9 & 43 & 73 & 85 & 61 & 93 & 40.7 & 53 & 0 \\
\hline 4 & 3 & E & 49 & 1.1 & 21 & 43 & 66 & 21 & 75 & 11.1 & 18.9 & 0 \\
\hline 4 & 3 & W & 54 & 1.2 & 23 & 46 & 68 & 20 & 76 & 18.9 & 14.1 & 0 \\
\hline 4 & 4 & E & 58 & 1.3 & 29 & 49 & 70 & 29 & 81 & 19.8 & 26.7 & 0 \\
\hline 4 & 4 & W & 61 & 1.4 & 31 & 52 & 73 & 27 & 83 & 32.5 & 19.8 & 0 \\
\hline 4 & 5 & $\mathrm{E}$ & 64 & 1.4 & 31 & 53 & 73 & 34 & 82 & 26 & 28.4 & 0 \\
\hline 4 & 5 & W & 65 & 1.5 & 34 & 56 & 75 & 31 & 84 & 42 & 24.6 & 0 \\
\hline 5 & 3 & $\mathrm{E}$ & 51 & 1.2 & 23 & 45 & 67 & 23 & 76 & 13.6 & 20.1 & 0 \\
\hline 5 & 3 & W & 44 & 1.2 & 23 & 41 & 65 & 20 & 73 & 12.7 & 15.9 & 0 \\
\hline 5 & 4 & $\mathrm{E}$ & 61 & 1.5 & 34 & 55 & 73 & 33 & 82 & 39.9 & 27.1 & 0 \\
\hline 5 & 4 & W & 62 & 1.5 & 34 & 56 & 75 & 30 & 84 & 41.8 & 21.4 & 0 \\
\hline 5 & 5 & $\mathrm{E}$ & 65 & 1.5 & 37 & 56 & 75 & 36 & 83 & 35.6 & 31.7 & 0 \\
\hline 5 & 5 & W & 62 & 1.5 & 38 & 53 & 73 & 33 & 82 & 32 & 28.3 & 0 \\
\hline 6 & 3 & $\mathrm{E}$ & 62 & 1.5 & 15 & 53 & 75 & 26 & 89 & 34 & 22 & 0 \\
\hline 6 & 3 & $\mathrm{~W}$ & 57 & 1.4 & 29 & 52 & 71 & 27 & 78 & 33.4 & 17.5 & 0 \\
\hline 6 & 4 & $\mathrm{E}$ & 61 & 1.5 & 33 & 54 & 73 & 32 & 83 & 30.8 & 28.6 & 0 \\
\hline 6 & 4 & W & 63 & 1.7 & 36 & 58 & 76 & 36 & 85 & 47.4 & 23.8 & 0 \\
\hline 6 & 5 & $\mathrm{E}$ & 67 & 1.7 & 40 & 59 & 77 & 39 & 84 & 43.2 & 33.2 & 0 \\
\hline 6 & 5 & W & 69 & 1.9 & 44 & 63 & 79 & 43 & 87 & 54.7 & 30.8 & 0 \\
\hline
\end{tabular}


Monitor roof openings have values ranging from $12-49 \%$, while sawtooth roof openings have zero $(0 \%)$ values for North Oriental $(\mathrm{N})$ apertures, $\sim 60 \%$ for South $(\mathrm{S})$ orientation openings and $14-33 \%$ for Eastern (E) and West (W) orientation. Skylight roof openings exhibit the largest variations, which are also depended on the type of glazing visible transmittance, with a permeability of 0.8 and values $>91 \%$, with a permeability of 0.7 and $87-93 \%$, and finally a low permeability 0.2 with values $<30 \%$, providing the highest values of all types.

In order to determine the degree of interdependence between the different results as presented in the above tables, the Kendal [58] and Spearman [59] correlation coefficients were calculated, both declaring the degree of hierarchical covariance between the two different parameters. It should be noted that the correlation coefficients with absolute values up to 0.5 indicate little interdependence between the tested variables, values ranging from 0.5 to 0.8 indicate moderate correlation, and those of 0.8 to 1.0 indicate strong interdependence of the size. Tables 8 and 9 present the best correlating values (Mean DA and ASE) for both Kendal and Spearman correlation coefficients.

Table 8. Mean DA Correlation Values.

\begin{tabular}{|c|c|c|c|c|c|c|c|c|c|c|c|}
\hline \multirow{2}{*}{\multicolumn{2}{|c|}{$\begin{array}{l}\text { MDA Correlation } \\
\text { Values }\end{array}$}} & \multicolumn{3}{|c|}{ Geometry of Openings } & \multicolumn{7}{|c|}{ Daylight Illuminance Metrics } \\
\hline & & \multirow{3}{*}{$\begin{array}{c}\text { Height } \\
0.260 \\
0.372\end{array}$} & \multirow{3}{*}{$\begin{array}{c}\text { Width } \\
0.878^{* *} \\
0.003\end{array}$} & \multirow{3}{*}{$\begin{array}{c}\text { Volume } \\
0.857^{* *} \\
0.002\end{array}$} & \multirow{3}{*}{$\frac{\text { DA }}{1.000^{* *}}$} & \multirow{3}{*}{$\frac{\text { MDF }}{1.000^{* *}}$} & \multirow{3}{*}{$\begin{array}{c}\text { DF } \\
0.986^{* *} \\
0.000\end{array}$} & \multirow{3}{*}{$\begin{array}{c}\text { MDA } \\
1.000\end{array}$} & \multirow{3}{*}{$\begin{array}{c}\text { MCDA } \\
0.986^{* *} \\
0.000\end{array}$} & \multirow{3}{*}{$\begin{array}{c}\text { DA }_{\text {MAX }} \\
0.986^{* *} \\
0.000\end{array}$} & \multirow{3}{*}{$\begin{array}{c}\text { UDI } \\
0.756^{*} \\
0.011\end{array}$} \\
\hline & Correl. & & & & & & & & & & \\
\hline Kendal & Sig. & & & & & & & & & & \\
\hline \multirow{2}{*}{ Spearman } & Correl. & 0.291 & $0.953 * *$ & $0.945^{* *}$ & $1.000^{* *}$ & $1.000 * *$ & $0.996^{* *}$ & 1.000 & $0.996^{* *}$ & $0.996^{* *}$ & $0.840 * *$ \\
\hline & Sig. & 0.447 & 0.000 & 0.000 & & & 0.000 & & 0.000 & 0.000 & 0.005 \\
\hline
\end{tabular}

${ }^{*}$ Correlation is significant at the 0.05 level, ${ }^{* *}$ Correlation is significant at the 0.01 level.

Table 9. Annual Sunlight Exposure Correlation Values.

\begin{tabular}{|c|c|c|c|c|c|c|c|c|c|c|c|}
\hline \multirow{2}{*}{\multicolumn{2}{|c|}{$\begin{array}{l}\text { ASE Correlation } \\
\text { Values }\end{array}$}} & \multicolumn{3}{|c|}{ Geometry of Openings } & \multicolumn{7}{|c|}{ Daylight Illuminance Metrics } \\
\hline & & \multirow{3}{*}{$\begin{array}{c}\text { Height } \\
0.260 \\
0.372\end{array}$} & \multirow{3}{*}{$\begin{array}{c}\text { Height } \\
0.878^{* *} \\
0.003\end{array}$} & \multirow{3}{*}{$\begin{array}{c}\text { Height } \\
0.857^{* *} \\
0.002\end{array}$} & \multirow{3}{*}{$\frac{\text { DA }}{1.000^{* *}}$} & \multirow{3}{*}{$\frac{\text { MDF }}{1.000^{* *}}$} & \multirow{3}{*}{$\begin{array}{c}\text { DF } \\
0.986^{* *} \\
0.000\end{array}$} & \multirow{3}{*}{$\begin{array}{c}\text { MDA } \\
1.000\end{array}$} & \multirow{3}{*}{$\begin{array}{c}\text { MCDA } \\
0.986^{* *} \\
0.000\end{array}$} & \multirow{3}{*}{$\begin{array}{c}\text { DA }_{\text {MAX }} \\
0.986^{* *} \\
0.000\end{array}$} & \multirow{3}{*}{$\begin{array}{c}\text { UDI } \\
0.756^{*} \\
0.011\end{array}$} \\
\hline Kondal & Correl. & & & & & & & & & & \\
\hline Kendal & Sig. & & & & & & & & & & \\
\hline \multirow{2}{*}{ Spearman } & Correl. & 0.291 & $0.953^{* *}$ & $0.945^{* *}$ & $1.000 * *$ & $1.000^{* *}$ & $0.996^{* *}$ & 1.000 & $0.996^{* *}$ & $0.996^{* *}$ & $0.840^{* *}$ \\
\hline & Sig. & 0.447 & 0.000 & 0.000 & & & 0.000 & & 0.000 & 0.000 & 0.005 \\
\hline
\end{tabular}

${ }^{*}$ Correlation is significant at the 0.05 level, ${ }^{* *}$ Correlation is significant at the 0.01 level.

It is obvious that the correlation of the height of the opening with the target daylight illuminance was very small. Thus, there is no significant effect on the increase of this geometric feature, or a significant interrelationship between the width of the aperture and the daylight illuminance levels. It has therefore been decided to choose the Mean Daylight Autonomy (MDA), along with the Annual Solar Exposure (ASE), as the main variables for the comparison of daylight performance. The results show that the orientation affects the various scenarios as follows. For monitors, the variance of MeanDA values for the two available orientations (N-S, E-W) was small, and did not exceed 2-5\%, while for our skylight, the variations were in the range of $\pm 10 \%$. Finally, in the case of the sawtooth roof, the differences were significantly greater, revealing the sensitivity to this parameter.

\section{Optimisation and Discussion}

As the overall performance of the saw-tooth type was better than the other types (Figure 9), it was selected for the final step of the optimisation methodology. The proposed methodology involves the employment of a penalty function algorithm. For the equinoctial day in spring, a number of hourly simulations were performed. The hourly illuminance values and the corresponding uniformity values were calculated for a grid located between two consecutive openings. Nineteen grids were examined, with the distance varying from $5 \mathrm{~m}$ to $23 \mathrm{~m}$ (using a $1 \mathrm{~m}$ step between two consecutive openings). The examined counterbalancing parameters for the cross correlation of the optimisation methodology were: (a) The average illuminance (ranging from $300 \mathrm{~lx}$, set as the target illuminance to $500 \mathrm{~lx}$, which was set as a value for over illumination), (b) the uniformity defined as the ratio between minimum 
to average (up to 0.4 ) and (c) the number of openings in the examined space (the smaller the better, in an effort to reduce construction costs). As the number of openings is increased, the distance of the consecutive openings becomes smaller, while the illuminance and uniformity values are increased. On the other hand, as the number of the openings is reduced, the distance of the consecutively spaced openings is increased. Thus, the illuminance and uniformity values are decreasing considerably, resulting in daylight inadequacy, as the values are below the target values.

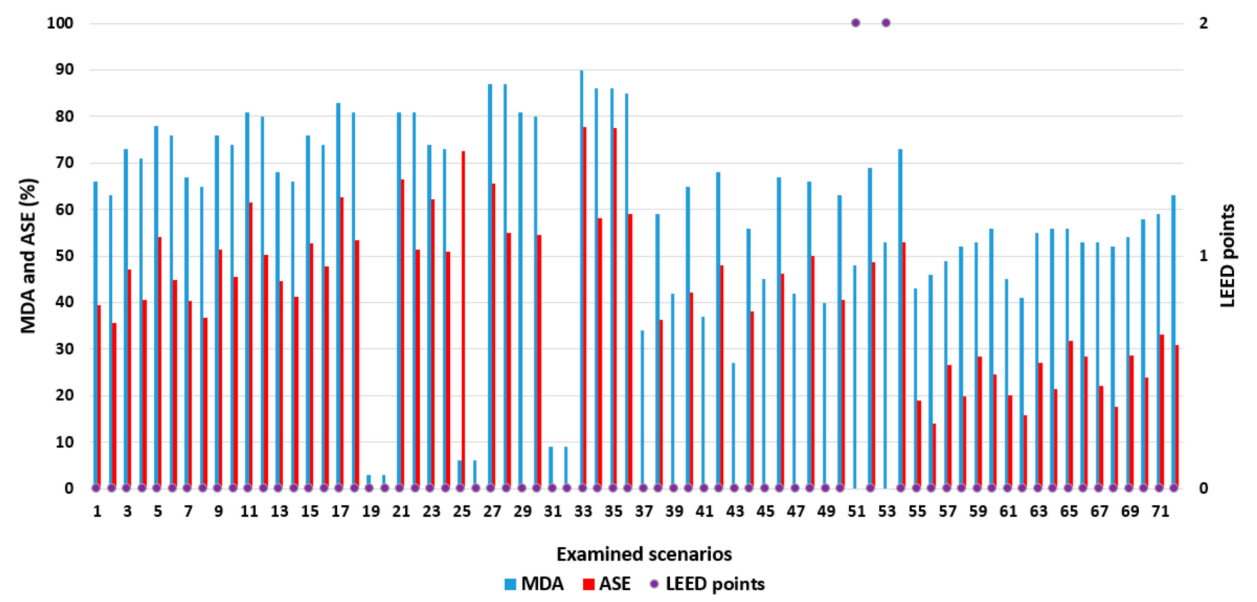

Figure 9. Selection of the sawtooth type for the final step of the optimisation methodology (LEED points: 2, ASE $0 \%$, MDA 53\%).

The results are presented in Table 10. The values are highlighted according to whether they fully (Green) or partially (Orange) conform to the aforementioned target. In more detail, orange colour corresponds to a uniformity index ( $\mathrm{min} /$ average) above 0.4 , with average illuminance values above 300 lx.

Table 10. Hourly average uniformity, illuminance and hours of sufficient lighting values for various distance steps between two consecutive openings (Green colour: The target value is fully fulfilled. Orange colour: The target value is partially fulfilled).

\begin{tabular}{|c|c|c|c|c|c|c|c|c|c|c|c|}
\hline \multirow{2}{*}{$\begin{array}{l}\text { Opening } \\
\text { Distance }\end{array}$} & \multicolumn{4}{|c|}{ Average Uniformity (\%) } & \multicolumn{4}{|c|}{ Average Illuminance (lx) } & \multicolumn{3}{|c|}{ Average No of $\mathrm{H}$} \\
\hline & Overcast & 21 March & 21 June & 21 December & Overcast & 21 March & 21 June & 21 December & 300 to $5001 x$ & $>5001 x$ & $>3001 x$ \\
\hline $5 \mathrm{~m}$ & 0.792 & 0.610 & 0.777 & 0.733 & 440 & 749 & 982 & 294 & 2.5 & 6.25 & 8.75 \\
\hline $6 \mathrm{~m}$ & 0.789 & 0.712 & 0.757 & 0.715 & 435 & 585 & 902 & 285 & 2.75 & 6 & 8.75 \\
\hline $7 \mathrm{~m}$ & 0.788 & 0.673 & 0.734 & 0.692 & 424 & 521 & 816 & 271 & 3.5 & 5.25 & 8.75 \\
\hline $8 \mathrm{~m}$ & 0.771 & 0.576 & 0.718 & 0.675 & 409 & 1012 & 754 & 257 & 3.25 & 5.25 & 8.5 \\
\hline $9 \mathrm{~m}$ & 0.749 & 0.380 & 0.691 & 0.656 & 397 & 1251 & 697 & 252 & 2.75 & 5.25 & 8 \\
\hline $10 \mathrm{~m}$ & 0.657 & 0.650 & 0.677 & 0.677 & 389 & 390 & 645 & 227 & 4 & 3.75 & 7.75 \\
\hline $11 \mathrm{~m}$ & 0.685 & 0.631 & 0.652 & 0.654 & 352 & 350 & 584 & 208 & 4.75 & 2.75 & 7.5 \\
\hline $12 \mathrm{~m}$ & 0.651 & 0.614 & 0.619 & 0.652 & 332 & 321 & 540 & 192 & 4.25 & 2 & 6.25 \\
\hline $13 \mathrm{~m}$ & 0.629 & 0.593 & 0.595 & 0.626 & 317 & 301 & 509 & 180 & 4.25 & 1.5 & 5.75 \\
\hline $14 \mathrm{~m}$ & 0.572 & 0.580 & 0.571 & 0.621 & 300 & 279 & 475 & 167 & 4.75 & 1 & 5.75 \\
\hline $15 \mathrm{~m}$ & 0.569 & 0.555 & 0.545 & 0.605 & 285 & 261 & 447 & 156 & 5.25 & 0 & 5.25 \\
\hline $16 \mathrm{~m}$ & 0.543 & 0.534 & 0.523 & 0.584 & 271 & 244 & 420 & 146 & 4.75 & 0 & 4.75 \\
\hline $17 \mathrm{~m}$ & 0.528 & 0.518 & 0.502 & 0.573 & 263 & 235 & 404 & 141 & 4.25 & 0 & 4.25 \\
\hline $18 \mathrm{~m}$ & 0.497 & 0.503 & 0.479 & 0.554 & 246 & 218 & 378 & 130 & 3.75 & 0 & 3.75 \\
\hline $19 \mathrm{~m}$ & 0.417 & 0.419 & 0.341 & 0.457 & 197 & 199 & 363 & 111 & 2.75 & 0 & 2.75 \\
\hline $20 \mathrm{~m}$ & 0.456 & 0.473 & 0.446 & 0.532 & 226 & 196 & 342 & 118 & 3.5 & 0 & 3.5 \\
\hline $21 \mathrm{~m}$ & 0.436 & 0.452 & 0.430 & 0.529 & 214 & 184 & 323 & 110 & 2.75 & 0 & 2.75 \\
\hline $22 \mathrm{~m}$ & 0.424 & 0.453 & 0.419 & 0.515 & 206 & 174 & 307 & 104 & 2 & 0 & 2 \\
\hline $23 \mathrm{~m}$ & 0.384 & 0.427 & 0.395 & 0.532 & 196 & 165 & 293 & 117 & 1 & 0 & 1 \\
\hline
\end{tabular}

\section{Selection of Optimum Solution}

A simple inverted penalty function algorithm has been proposed for the identification of the optimum distance value between two consecutively spaced openings. The form of a Boolean algebraic summation of the values was used, where the optimum case study was in conformance with the selected design criteria. Each solution has been valuated with 1 point for every fully fulfilled criterion (Green), 0.5 points for a partially fulfilled criterion (Orange) and 0 for failing to conform with all of 
the criteria. Table 11 presents the final results, while a simple colouring scheme has been employed for quick visual inspection. As such, the top quartile solutions have been highlighted with Green, while all above average solutions have been highlighted Orange. The identification of the optimum solution in terms of distance values between two consecutive openings has led to the conclusion that the optimum distance should be in the range of $10 \mathrm{~m}$ to $13 \mathrm{~m}$ (Table 11, top quartile values).

Table 11. Inverted penalty function algorithm results.

\begin{tabular}{|c|c|c|c|c|c|c|c|c|c|c|c|c|c|c|c|c|c|c|c|}
\hline Distance (m) & 5 & 6 & 7 & 8 & 9 & 10 & 11 & 12 & 13 & 14 & 15 & 16 & 17 & 18 & 19 & 20 & 21 & 22 & 23 \\
\hline Penalty Function & 8 & 8 & 8 & 8 & 7 & 10.5 & 10.5 & 9.5 & 9.5 & 8 & 5.5 & 5 & 5 & 5 & 3.5 & 4 & 4 & 4 & 2 \\
\hline & & $<$ & 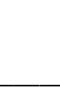 & & & $\begin{array}{l}<-\mathrm{Be} \\
<- \\
\mathrm{e} \text { Aver }\end{array}$ & $\begin{array}{l}\text { st -> } \\
\text { Top Q } \\
\text { age Va }\end{array}$ & $\begin{array}{l}\text { uartile } \\
\text { lues - }\end{array}$ & $\longrightarrow$ & & & & & & & & & & \\
\hline
\end{tabular}

\section{Conclusions}

The results indicate the significant contribution of the roof opening type in the overall ability of daylight to act as a complementary or exclusive workbench light source in an industrial building. Moreover, the results showed the superiority of the north opening orientations combined with the partially indirect light ingress (i.e., sawtooth and monitor roof opening arrangements). In these case studies the high ASE values are avoided, while the daylight uniformity is high with reduced illuminance spikes. On the other hand, skylights have been deemed quite an inadequate arrangement, yielding highly concentrated illuminance levels. For monitor roofs a reduction of 55\% (max) was observed between the E-W and N-S orientations; For sawtooth there was an increase of $22 \%$ (max) between $\mathrm{N}$ and $\mathrm{S}$ and $2 \%$ (max) between the $\mathrm{E}$ and $\mathrm{W}$ orientations; while skylights presented a rather erratic behaviour (ASE values ranged from $2 \%$ to more than $90 \%$ ). Overall, it seems that a sawtooth roof represents the best choice for a source of daylight in industrial buildings at the examined geographic location. Despite the lack of available LEED v4 values for industrial building types, the examined case studies were investigated using LEED v4 as a criterion in order to assign the relevant points. Sawtooth was the only roof type with case studies resulting in 2 points. Both cases had ASE values equal to $0 \%$. The selected one with the larger MDA value was chosen as the best performing one.

Above a certain threshold, daylight is no longer useful, as the space is "saturated" with light. The large number of openings can contribute to higher construction costs. Up to now, constructors in Greece use rules of a thumb for determining the type of the horizontal openings or the number of the openings at the initial design phase, except the minimum surface of the external opening. It is therefore expected that the designer will endeavour to make use of the minimum number of openings for a given solution that fulfils the daylight criteria. An optimisation tool was proposed in order to investigate the optimum distance between the openings. A penalty function algorithm was developed, taking into account the target illuminance values (from $300 \mathrm{~lx}$ to $500 \mathrm{~lx}$ ), uniformity $(>0.4$ minimum to average illuminance) and the overall number of roof openings in a given space (the small number of roof openings reduces the construction costs). This resulted in an optimum range from $10 \mathrm{~m}$ and $13 \mathrm{~m}$. With the addition of the constructability and maintenance, the optimum solution could be the one in which the distance between two consecutive openings can vary between $10 \mathrm{~m}$ and $11 \mathrm{~m}$.

Author Contributions: Conceptualization, T.M. and L.D.; methodology, T.M. and L.D.; software, T.M.; validation, T.M. and L.D.; formal analysis, T.M.; investigation, T.M.; resources, T.M. and L.D.; data curation, T.M. and L.D.; writing—original draft preparation, T.M.; writing—review and editing, L.D.; visualization, T.M. and L.D.; supervision, L.D.

Funding: This research received no external funding.

Conflicts of Interest: The authors declare no conflict of interest. 


\section{References}

1. Santamouris, M. Green commercial buildings save energy. Nat. Sustain. 2018, 1, 613-614. [CrossRef]

2. Santamouris, M.; Ban-Weiss, G.; Osmond, P.; Paolini, R.; Synnefa, A.; Cartalis, C.; Muscio, A.; Zinzi, M.; Morakinyo, T.; Ng, E.; et al. Progress in urban greenery mitigation science - assessment methodologies advanced technologies and impact on cities. J. Civ. Eng. Manag. 2018, 24, 638-671. [CrossRef]

3. Marinakis, V.; Doukas, H. An Advanced IoT-based System for Intelligent Energy Management in Buildings. Sensors 2018, 18, 610. [CrossRef] [PubMed]

4. Tsoka, S.; Tsikaloudaki, K.; Theodosiou, T. Coupling a Building Energy Simulation Tool with a Microclimate Model to Assess the Impact of Cool Pavements on the Building's Energy Performance Application in a Dense Residential Area. Sustainability 2019, 11, 2519. [CrossRef]

5. Theodosiou, T.; Tsikaloudaki, K.; Tsoka, S.; Chastas, P. Thermal bridging problems on advanced cladding systems and smart building facades. J. Clean. Prod. 2019, 214, 62-69. [CrossRef]

6. Doulos, L.; Santamouris, M.; Livada, I. Passive Cooling of Outdoor Urban Spaces. The Role of Materials. Sol. Energy 2004, 77, 231-249. [CrossRef]

7. Giama, E.; Papadopoulos, A.M. Construction materials and green building certification. Key Eng. Mater. 2016, 666, 89-96. [CrossRef]

8. Droutsa, K.G.; Kontoyiannidis, S.; Dascalaki, E.G.; Balaras, C.A. Mapping the energy performance of hellenic residential buildings from EPC (energy performance certificate) data. Energy 2016, 98, 284-295. [CrossRef]

9. Pallis, P.; Gkonis, N.; Varvagiannis, E.; Braimakis, K.; Karellas, S.; Katsaros, M.; Vourliotis, P.; Sarafianos, D. Towards NZEB in Greece: A comparative study between cost optimality and energy efficiency for newly constructed residential buildings. Energy Build. 2019, 198, 115-137. [CrossRef]

10. Doukas, H.; Siskos, E.; Psarras, J.; Malamatenios, C.; Tournaki, S.; Tsoutsos, T. Qualification roadmap empowering the Greek building sector workforce in the field of energy. Renew. Sustain. Energy Rev. 2016, 65, 992-1004. [CrossRef]

11. Fantozzi, F.; Gargari, C.; Rovai, M.; Salvadori, G. Energy Upgrading of Residential Building Stock: Use of Life Cycle Cost Analysis to Assess Interventions on Social Housing in Italy. Sustainability 2019, 11, 1452. [CrossRef]

12. Giovannini, L.; Favoino, F.; Lo Verso, V.R.M.; Pellegrino, A.; Serra, V. A Simplified Approach for the Annual and Spatial Evaluation of the Comfort Classes of Daylight Glare Using Vertical Illuminances. Buildings 2018, 8, 171. [CrossRef]

13. Gürlich, D.; Reber, A.; Biesinger, A.; Eicker, U. Daylight Performance of a Translucent Textile Membrane Roof with Thermal Insulation. Buildings 2018, 8, 118. [CrossRef]

14. Pierson, C.; Wienold, J.; Bodart, M. Daylight Discomfort Glare Evaluation with Evalglare: Influence of Parameters and Methods on the Accuracy of Discomfort Glare Prediction. Buildings 2018, 8, 94. [CrossRef]

15. Tzempelikos, A. Advances on daylighting and visual comfort research. Build. Environ. 2017, 113, 1-4. [CrossRef]

16. Doulos, L.T.; Kontadakis, A.; Madias, E.N.; Sinou, M.; Tsangrassoulis, A. Minimizing energy consumption for artificial lighting in a typical classroom of a Hellenic public school aiming for near Zero Energy Building using LED DC luminaires and daylight harvesting systems. Energy Build. 2019, 194, 201-217. [CrossRef]

17. Madias, E.N.D.; Doulos, L.T.; Kontaxis, P.A.; Topalis, F.V. A decision support system for techno-economic evaluation of indoor lighting systems with LED luminaires. Oper. Res. 2019, 1-20. [CrossRef]

18. Manolis, E.; Doulos, L.; Niavis, S.; Canale, L. The impact of energy efficiency indicators on the office lighting planning and its implications for office lighting market. In Proceedings of the 19th EEEIC International Conference on Environment and Electrical Engineering, Genoa, Italy, 11-14 June 2019.

19. Topalis, F.V.; Doulos, L.T. Ambient Light Sensor Integration. In Handbook of Advanced Lighting Technology; Springer: Cham, Switzerland, 2017; pp. 607-634.

20. Doulos, L.; Tsangrassoulis, A.; Topalis, F.V. Multi-criteria decision analysis to select the optimum position and proper field of view of a photosensor. Energy Convers. Manag. 2014, 86, 1069-1077. [CrossRef]

21. Adam, G.K.; Kontaxis, P.A.; Doulos, L.T.; Madias, E.N.D.; Bouroussis, C.A.; Topalis, F.V. Embedded microcontroller with a CCD camera as a digital lighting control system. Electronics 2019, 8, 33. [CrossRef]

22. Bellia, L.; Fragliasso, F.; Stefanizzi, E. Why are daylight-linked controls (DLCs) not so spread? A literature review. Build. Environ. 2016, 106, 301-312. [CrossRef] 
23. Bellia, L.; Fragliasso, F. Automated daylight-linked control systems performance with illuminance sensors for side-lit offices in the Mediterranean area. Autom. Constr. 2019, 100, 145-162. [CrossRef]

24. Bellia, L.; Fragliasso, F. Evaluating performance of daylight-linked building controls during preliminary design. Autom. Constr. 2018, 93, 293-314. [CrossRef]

25. Salvadori, G.; Fantozzi, F.; Rocca, M.; Leccese, F. The Energy Audit Activity Focused on the Lighting Systems in Historical Buildings. Energies 2016, 9, 998. [CrossRef]

26. Eltaweel, A.; Su, Y. Evaluation of Suitability of a Parametrically Controlled Louvers for Various Orientations throughout a Year Comparing to an Existing Case. Buildings 2017, 7, 109. [CrossRef]

27. Campanile, C.; Leccese, F.; Rocca, M.; Salvadori, G. Energy saving exploiting light availability: A new method to evaluate daylight contribution. In Proceedings of the BSA 2015-2nd IBPSA, Conference on Building Simulation Applications, Bozen, Italy, 4-6 February 2015; Volume 1, pp. 239-246, ISBN 978-88-6046-074-5.

28. Tywoniak, J.; Calta, V.; Staněk, K.; Novák, J.; Maierová, L. The Application of Building Physics in the Design of Roof Windows. Energies 2019, 12, 2300. [CrossRef]

29. Kim, I.-T.; Kim, Y.-S.; Cho, M.; Nam, H.; Choi, A.; Hwang, T. High-Performance Accuracy of Daylight-Responsive Dimming Systems with Illuminance by Distant Luminaires for Energy-Saving Buildings. Energies 2019, 12, 731. [CrossRef]

30. Li, J.; Ban, Q.; Chen, X.J.; Yao, J. Glazing Sizing in Large Atrium Buildings: A Perspective of Balancing Daylight Quantity and Visual Comfort. Energies 2019, 12, 701. [CrossRef]

31. Kim, C.-H.; Kim, K.-S. Development of Sky Luminance and Daylight Illuminance Prediction Methods for Lighting Energy Saving in Office Buildings. Energies 2019, 12, 592. [CrossRef]

32. Kwon, C.W.; Lee, K.J. Integrated Daylighting Design by Combining Passive Method with DaySim in a Classroom. Energies 2018, 11, 3168. [CrossRef]

33. Acosta, I.; Campano, M.Á.; Domínguez-Amarillo, S.; Muñoz, C. Dynamic Daylight Metrics for Electricity Savings in Offices: Window Size and Climate Smart Lighting Management. Energies 2018, 11, 3143. [CrossRef]

34. Katunský, D.; Dolníková, E.; Doroudiani, S. Integrated Lighting Efficiency Analysis in Large Industrial Buildings to Enhance Indoor Environmental Quality. Buildings 2017, 7, 47. [CrossRef]

35. Bunjongjit, S.; Ngaopitakkul, A. Feasibility Study and Impact of Daylight on Illumination Control for Energy-Saving Lighting Systems. Sustainability 2018, 10, 4075. [CrossRef]

36. Lee, J.; Boubekri, M.; Liang, F. Impact of Building Design Parameters on Daylighting Metrics Using an Analysis, Prediction, and optimisation Approach Based on Statistical Learning Technique. Sustainability 2019, 11, 1474. [CrossRef]

37. Chen, L.-Y.; Chen, S.-H.; Dai, S.-J.; Kuo, C.-T.; Wang, H.-C. Spectral design and evaluation of OLEDs as light sources. Org. Electron. 2014, 15, 2194-2209. [CrossRef]

38. Tsangrassoulis, A.; Doulos, L.; Santamouris, M.; Fontoynont, M.; Maamari, F.; Wilson, M.; Jacobs, A.; Solomon, J.; Zimmerman, A.; Pohl, W. On the energy efficiency of a prototype hybrid daylighting system. Sol. Energy 2005, 79, 56-64. [CrossRef]

39. Doulos, L.T.; Tsangrassoulis, A.; Kontaxis, P.A.; Kontadakis, A.; Topalis, F.V. Harvesting daylight with LED or T5 fluirescent lamps? The role of dimming. Energy Build. 2017, 140, 336-347. [CrossRef]

40. Doulos, L.; Tsangrassoulis, A.; Topalis, F. The role of spectral response of photosensors in daylight responsive systems. Energy Build. 2008, 40, 588-599. [CrossRef]

41. Doulos, L.; Tsangrassoulis, A.; Topalis, F. Quantifying energy savings in daylight responsive systems: The role of dimming electronic ballasts. Energy Build. 2008, 40, 36-50. [CrossRef]

42. Kontadakis, A.; Tsangrassoulis, A.; Doulos, L.; Topalis, F. An active sunlight redirection system for daylight enhancement beyond the perimeter zone. Build. Environ. 2017, 113, 267-279. [CrossRef]

43. Kontadakis, A.; Tsangrassoulis, A.; Doulos, L.; Zerefos, S.A. A Review of Light Shelf Designs for Daylit Environments. Sustainability 2018, 10, 71. [CrossRef]

44. Mushtaha, E.; Kana'an, B.A.; Al-Jawazneh, R.A.; Hammad, R.S. Effect of using different light pipe parameters on the daylight quality in buildings: The case of Jordan. Int. J. Green Energy 2016, 13, 1590-1598. [CrossRef]

45. Huang, Y.; Luo, W.; Wang, H.; Feng, S.; Kuo, C.; Lu, C. How Smart LEDs Lighting Benefit Color Temperature and Luminosity Transformation. Energies 2017, 10, 518. [CrossRef]

46. Chen, Y.; Liu, J.; Pei, J.; Cao, X.; Chen, Q.; Jiang, Y. Experimental and simulation study on the performance of daylighting in an industrial building and its energy saving potential. Energy Build. 2014, 73, 184-191. [CrossRef] 
47. Asdrubali, F. Daylighting performance of sawtooth roofs of industrial buildings. Light. Res. Technol. 2003, 35, 343-359. [CrossRef]

48. Bellia, L.; Boccia, G.; Fazzito, M.; Di Serafino, G.; Fragliasso, F.; Migiarra, P.; Moscarella, L.; Stefanizzi, E. A lighting retrofit intervention for energy savings and comfort optimisation in an industrial building 2016. In Proceedings of the 9th International Conference Improving Energy Efficiency in Commercial Buildings and Smart Communities, Frankfurt, Germany, 16-18 March 2016.

49. Paule, B.; Irissou, J.-F.; Saunier, G. Daylighting optimisation of the new factory of Turbomeca in Bordes, France. In Proceedings of the the 23rd Conference on Passive and Low Energy Architecture, Geneva, Switzerland, 6-8 September 2006.

50. Wang, X.; Kendrick, C.; Ogden, R.; Walliman, N.; Baiche, B. A case study on energy consumption and overheating for a UK industrial building with rooflights. Appl. Energy 2013, 104, 337-344. [CrossRef]

51. Stojkovic, M.; Pucar, M.; Krstic-Furundzic, A. Daylight performance of adapted industrial buildings. Archit. Civ. Eng. 2016, 14, 59-74. [CrossRef]

52. Katunský, D.; Dolníková, E.; Dolník, B. Daytime Lighting Assessment in Textile Factories Using Connected Windows in Slovakia: A Case Study. Sustainability 2018, 10, 655. [CrossRef]

53. Acosta, I.; Navarro, J.; Sendra, J.J. Daylighting design with lightscoop skylights: Towards an optimisation of shape under overcast sky conditions. Energy Build. 2013, 60, 232-238. [CrossRef]

54. Acosta, I.; Navarro, J.; Sendra, J.J. Towards an analysis of the performance of lightwell skylights under overcast sky conditions. Energy Build. 2013, 64, 10-16. [CrossRef]

55. Acosta, I.; Navarro, J.; Sendra, J.J. Towards an analysis of the performance of monitor skylights under overcast sky conditions. Energy Build. 2015, 88, 248-261. [CrossRef]

56. Energy Plus. Climatic Data. Available online: https://energyplus.net/weather (accessed on 20 June 2019).

57. EN 12464-1. Lighting of Work Places_Part 1: Indoor Work Places. Available online: https://infostore. saiglobal.com/preview/98701186098.pdf?sku=861397_SAIG_NSAI_NSAI_2049330 (accessed on 30 May 2019).

58. Kendall, M. A New Measure of Rank Correlation. Biometrika 1938, 30, 81-89. [CrossRef]

59. Spearman, C. The proof and measurement of association between two things. Am. J. Psychol. 1904, 15, 72-101. [CrossRef]

(C) 2019 by the authors. Licensee MDPI, Basel, Switzerland. This article is an open access article distributed under the terms and conditions of the Creative Commons Attribution (CC BY) license (http://creativecommons.org/licenses/by/4.0/). 